Article

\title{
Assessing the Contributions of Urban Light Rail Transit to the Sustainable Development of Addis Ababa
}

\author{
Jackson Sekasi ${ }^{1, * \mathbb{D}}$ and Mauro Luiz Martens ${ }^{2}$ \\ 1 Railway Engineering Civil Infrastructure Department, Addis Ababa Institute of Technology, \\ Addis Ababa University, Addis Ababa 1000, Ethiopia \\ 2 Production Engineering Department, Polytechnic School, University of São Paulo, Butantã, \\ São Paulo 05501-010, Brazil; mauro.martens@usp.br \\ * Correspondence: jackson.sekasi@aait.edu.et; Tel.: +251-987006422
}

Citation: Sekasi, J.; Martens, M.L. Assessing the Contributions of Urban Light Rail Transit to the Sustainable Development of Addis Ababa. Sustainability 2021, 13, 5667. https:// doi.org/10.3390/su13105667

Academic Editor: Marilisa Botte

Received: 19 April 2021

Accepted: 10 May 2021

Published: 18 May 2021

Publisher's Note: MDPI stays neutral with regard to jurisdictional claims in published maps and institutional affiliations.

Copyright: (c) 2021 by the authors. Licensee MDPI, Basel, Switzerland. This article is an open access article distributed under the terms and conditions of the Creative Commons Attribution (CC BY) license (https:// creativecommons.org/licenses/by/ $4.0 /)$.

\begin{abstract}
Many of the existing urban transport infrastructures in developing African cities are challenged by the mobility demands of their ever-increasing population and increased vehicle capacity. To address these transportation challenges, the Federal government of Ethiopia through the Ethiopian Railway Corporation (ERC) constructed and operates the Addis Ababa light rail transit (AA-LRT). Currently, many other African cities are following in action. This study aims to assess the contributions to sustainable development derived from the services of urban light rail in Addis Ababa. Cross-sectional quantitative research by means of a structured questionnaire survey considering key variables of social, economic, and environmental transport sustainability dimensions was conducted in Addis Ababa. Dimension-wise, the collected data was then analysed in order to measure the contributions made by AA-LRT and to identify the relations amongst each considered variable and each sustainability dimension. The findings of the study indicate a high level of perceived contributions of the economic sustainability dimension as compared to social and environmental sustainability. The study suggests an improved consideration of the environmental and social dimension for a holistic approach to transport sustainability of the city.
\end{abstract}

Keywords: sustainability; railway transport; sustainable development; urban rail; Addis Ababa light rail transit; transport infrastructure; sustainable urban transport

\section{Introduction}

Addis Ababa city, similar to many of Africa's rapidly growing metropolises is challenged by the need for modern urban mobility systems to answer calls of an inefficient public transport service. A great percentage of the current transport system in many of these cities is almost automobile dominated [1], with the old fleet being unsustainable due to excessive air and noise pollution, high cost, congestion, and safety problems, among others. The desire to overcome these difficulties is therefore making economies advocate for increased effectual and sustainable solutions [2]. Since urban light railway infrastructure serves as a mainstay of urban mobility in conurbations [3-5], due to its benefits such as mass transit capacity, comfortability, fast speed, safety reliability, better environmental congestion and, mitigation impacts, Addis Ababa responded by implementing an urban LRT through the city and its suburbs.

Light Rail Transit (LRT) establishments are massively known to progress "sustainable urban mobility policies" in and around many municipalities due to their ability in changing urban surroundings together with conditions that are necessary in relation to terms of planning for their effective integration [6]. It is also notable that in discussing issues of the modern economy, a transport factor must be involved due to its influences in uplifting the social, environmental, and economic status [7]. By promoting the development of industries and quick accessibility, which improves the standards of living, urban rail transit positions itself as great leverage towards urban economy. 
This paper presents an assessment of the contributions of LRT to the sustainability of Addis Ababa in terms of development (in the perspective of sustainable transportation development). Many recent studies have been conducted to analyze the contribution of LRT to the sustainable development of several cities across the world but in consideration of Ethiopia, limited work to this effect has been conducted. LRT infrastructure delivery with minimal sustainability assessment can lead to objectionable socio-economic and environmental effects for the stakeholders [8]. Although the state of knowledge has substantially improved in recent years as a result of these studies, many questions still remain open, and new evidence is clearly needed [9], especially in Africa. The question that arises is: how has LRT contributed to the sustainability of Addis Ababa?

A study by [10] concludes that the emergence of light rail as a new mobility system is not just a matter of creating capacity and reducing travel time but has many other rationalities attached. The authors therefore believe that one of these rationalities is the desire to achieve sustainable development. While some new LTR projects in middle income developing cities, may have limited economic and practical value [11], and some RLT project plans have been shelved mainly for financing reasons [12], many RLT operations have been a success, achieved intended objectives, and contributed to sustainability of their localities [13]. Additionally, when you consider cities that are moving towards the adoption of LRT, enough sustainability assessment has not been executed on the extensive LRT infrastructure projects. This may lead to hardships that increase costs and cause negative socio-economic and environmental consequences to the light-rail provider and the community [8].

In line with the above perspective and using formulated variables that are principal in transport sustainability, the research aims to utilize the survey method to collect perceptionbased responses amongst Addis Ababa residents on the contributions of AA-LRT to the sustainable development of Addis Ababa. Results from the collected data analysis will therefore be key in addressing the study question by indicating to what extent AA-RLT has contributed to sustainable development of Addis Ababa in the realm of the three dimensions; economic, social, and environmental sustainability dimensions, as coined by the Brundtland report $[14,15]$. The analysis will also try to understand the relationship among variables in each dimension.

The paper is structured in the following format. Section 2 provides a brief description of Addis Ababa city, its Light Rail Transit (AA-LRT), and sustainability approach. Then, Section 3 reviews published available literature on light rail transit and sustainability. Section 4 details materials and methods of the study, which includes the study duration and collection of both qualitative and quantitative data, particularly from a survey conducted among the residents of Addis together with data collected from ERC and other organizations. Section 5 provides the results from data analysis while Section 6 reports discussions of the results and deduced conclusions of the study, points out the limitations of the study and proposes directions for future research.

\section{Background}

Addis Ababa, which houses close to $25 \%$ of the city dwellers, is the capital city of Ethiopia, the largest metropolis in the country, and among Africa's fastest-rising cities. It is the growth engine for Ethiopia and a major pillar in the country's vision to become a middle-income, carbon-neutral, and resilient economy by 2025 [16]. Addis Ababa light rail transit (AA-RLT) is the first light rail and rapid transit in eastern and sub-Saharan Africa. It was put into operation in 2015 by Ethiopia Railways Cooperation (ERC) which is Mandated to advance railway infrastructure and deliver commuter and cargo rail transportation services in Ethiopia [17]. It is an electrified light rail transit with 41 stations and a total length of $34.25 \mathrm{~km}$ of rail lines. As indicated in Figure 1 below, it has two lines, one running north-south from Menelik Square to Kality $(16.9 \mathrm{~km})$ serving 23 stations and the other running east-west from Ayat to Tor Hailoch $17.35(\mathrm{~km})$ with the two lines sharing a $2.7 \mathrm{~km}$ section of the track in the city center serving 16 stations. On both lines of the 
LRT, trains cannot travel beyond $80 \mathrm{~km} / \mathrm{h}$, putting their normal operational speed at $65 \mathrm{~km} / \mathrm{h}$ with a maximum network designed hourly flow of 15,000 passengers per hour per direction (PPHPD) [8]. Intended to mitigate and control the increasing traffic jam in Addis Ababa, whose populace has now exceeded 5 million occupants, the light rail was built by China Railway Engineering Corporation at a hooping sum close to US $\$ 475 \mathrm{~m}$, and $85 \%$ of the project was financed by loans advanced from export-import (EXIM) Bank of China (https:/ / www.railwaygazette.com/addis-ababa-light-rail-opens/41388.article (accessed on 22 January 2020).

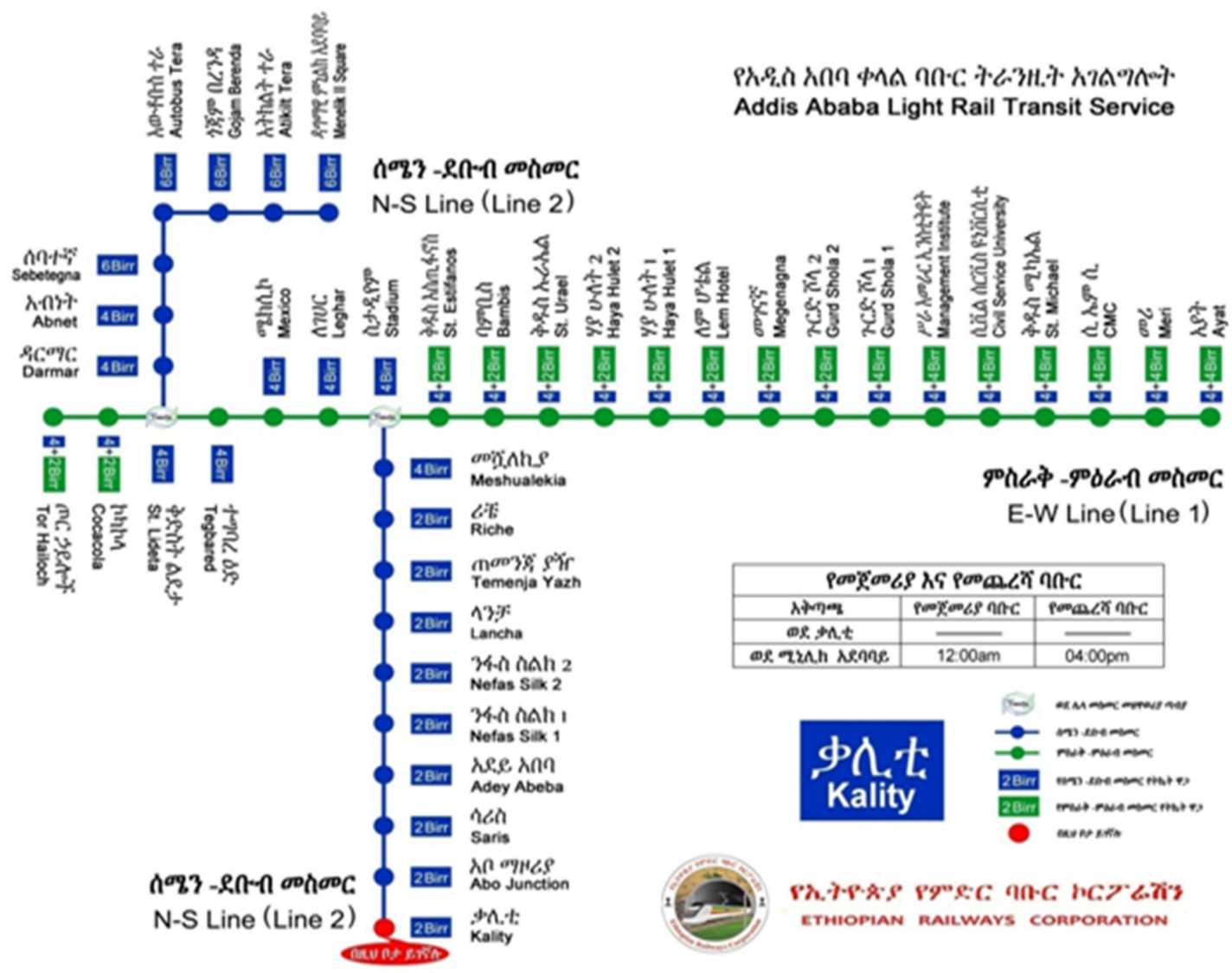

Figure 1. Operational stations along the AA-RLT route map. (Source http:/ / www.aalrt.gov.et/maps.php (accessed on 29 December 2019); Photo taken by author inside the AA-LRT train).

\section{Literature Review}

The European Conference of Ministers of Transport defines light rail as a rail-borne form of transport that can be developed in stages ranging from the modern tram to a rapid transport system operating on its own right of way, be it underground, at ground level, or elevated [18]. Ideally, light rail is a form of railway urban transportation system, that is not a heavy traditional form of railways. The adoption of light rail in Africa is gaining momentum, as can be seen in Table 1 below. 
Table 1. Light rail projects in Africa (Source: https:/ / en.wikipedia.org/wiki/Urban_rail_transit_in_Africa (accessed on 29 December 2019).

\section{Urban Railway Transit in Africa}

\begin{tabular}{|c|c|c|}
\hline \multirow[t]{2}{*}{ Suburban rail } & Operation & $\begin{array}{c}\text { Nairobi rail service, Botswana Railways (BR Express), Dar el salaam } \\
\text { commuter rail, Metrorail western cape, Metrorail eastern cape, } \\
\text { Metrorail Gauteng, Metrorail KwaZulu-Natal, Al Bidaoui, Gautrain, } \\
\text { Petit train de banlieue }\end{array}$ \\
\hline & Under construction & Train express regional \\
\hline \multirow{2}{*}{ Rapid transit } & Operation & Algiers metro, Cairo metro. \\
\hline & Under construction & Abidjan metro, Lagos rail mass transit \\
\hline \multirow[t]{2}{*}{ Light rail } & Operation & $\begin{array}{c}\text { Addis Ababa light rail, Abuja light rail, Métro léger de Tunis, Sidi bel } \\
\text { Abbés tramway, Trams in Alexandria, Casablanca tramway, Oran } \\
\text { tramway, Algiers tramway, Constantine tramway, Ouargla tramway, } \\
\text { Sétif tramway, Rabat-salé tramway }\end{array}$ \\
\hline & Proposed & Nairobi light rail, Greater Kampala light rail \\
\hline
\end{tabular}

The comparison of the basic characteristic of light rail as compared to the traditional rail can be seen in Table 2 below.

Table 2. A comparison of basic characteristics of light and heavy rail.

\begin{tabular}{ccc}
\hline Characteristics & Light Rail & Heavy Rail \\
\hline Population of the city & $100,000-1$ million & $>500,000$ \\
\hline Type of line & Mainly separated from road traffic on street level & Completely separated from road traffic \\
\hline Medium distance between stops (m) & $250-1200$ & $1000-5000$ \\
\hline Engineering & Light & Medium to heavy \\
\hline Maximal gradients (\%) & $8-10$ & 3 \\
\hline Minimal Radius (M) & $15-25$ & 200 \\
\hline Carriage weight (t) & $<20$ & $40-50$ \\
\hline Maximal frequency (trains/hr) & $40-60$ & $24-40$ \\
\hline Transport capacity (Passengers $/ \mathrm{hr})$ & $8000-15,000$ & $30,000-60,000$ \\
\hline Average speed (Km/hr) & $10-40$ & $40-80$
\end{tabular}

Source: adopted from [18].

There is a growing body of literature related to the contributions derived from and the diverse effects of LRT projects in developing cities. Other studies have focused on the societal and commercial consequences of urban rail and light rail transit (LRT) as their main subjects of investigation. Even in the face of biting economic hardships, several developing economies in Sub-Saharan Africa and South Asia have joined the trend and are earmarking railway infrastructure projects in their strategic development plans for the next 10 to 30 years [19]. Railway infrastructure ventures are a paramount gesture and indicate one of man's greatest innovations towards the achievement of Sustainable Development Goals. Africa's commitment towards the development of RLT services is presented in Table 3 below. 
Table 3. Light Rail projects by region and implementation status.

\begin{tabular}{|c|c|c|c|c|c|c|c|c|c|c|c|c|}
\hline \multirow[b]{3}{*}{ Region } & \multicolumn{9}{|c|}{ Under Construction and Commissioning } & & & \\
\hline & \multirow[b]{2}{*}{$\begin{array}{c}\text { No of } \\
\text { Projects }\end{array}$} & \multicolumn{4}{|c|}{ Track Length (km) } & \multicolumn{4}{|c|}{ Min Estimated Project Cost (bn \$) } & \multicolumn{3}{|c|}{ Cost in $\mathrm{Km}$ in $\mathrm{m} \$$ in } \\
\hline & & Total & $\%$ of World & $\begin{array}{c}\text { Low/Middle } \\
\text { Income Countries }\end{array}$ & $\begin{array}{c}\% \text { of } \\
\text { World }\end{array}$ & Total & $\begin{array}{c}\% \text { of } \\
\text { World }\end{array}$ & $\begin{array}{c}\text { Low/Middle } \\
\text { Income Countries }\end{array}$ & $\begin{array}{c}\% \text { of } \\
\text { World }\end{array}$ & $\begin{array}{c}\text { No of } \\
\text { Projects }\end{array}$ & Total & $\begin{array}{c}\text { Low/Middle } \\
\text { Income Countries }\end{array}$ \\
\hline Africa & 15 & 313 & $23 \%$ & 313 & $22.6 \%$ & 10.1 & $16 \%$ & 10.1 & $15.6 \%$ & 8 & 70.6 & 70.6 \\
\hline Asia & 36 & 506 & $37 \%$ & 380 & $27.4 \%$ & 18.5 & $29 \%$ & 12.3 & $19.0 \%$ & 16 & 69.7 & 73.5 \\
\hline Australasia & 3 & 31 & $2 \%$ & 0 & $0.0 \%$ & 2.4 & $4 \%$ & 0.0 & $0.0 \%$ & 3 & 75.5 & $\mathrm{~N} / \mathrm{A}$ \\
\hline North America & 22 & 265 & $19 \%$ & 23 & $1.6 \%$ & 25.2 & $39 \%$ & 1.4 & $2.2 \%$ & 21 & 99.7 & 63.9 \\
\hline South America & 3 & 30 & $2 \%$ & 30 & $2.1 \%$ & 0.5 & $1 \%$ & 0.5 & $0.8 \%$ & 3 & 18.5 & 18.5 \\
\hline World (constr.) & 110 & 1386 & $100 \%$ & 745 & $53.8 \%$ & 64.8 & $100 \%$ & 24.4 & $37.7 \%$ & 80 & 67.4 & $\mathrm{~N} / \mathrm{A}$ \\
\hline China & 16 & & & 286 & $21 \%$ & & & 11.4 & & 8 & & 88.8 \\
\hline India & 0 & & & 0 & $0 \%$ & & & 0 & & 0 & & $\mathrm{~N} / \mathrm{A}$ \\
\hline
\end{tabular}


Sustainable Development (SD), as explained in the United Nations World Commission on Environment and Development acknowledging the 1987 Brundtland Commission report: "is the development that meets the needs of the present without compromising the ability of future generations to meet their own needs" [8,21-25]. According to [26], sustainability is synonymous with sustainable development. This implies that sustainability and sustainable development [27] are used interchangeably, as is the case in this paper. Elkington (1997) synthesized these dimensions as the Triple-P or the Triple Bottom Line. The United Nations 2005 World Summit Outcome Document refers to the "interdependent and mutually reinforcing pillars" of sustainable development as economic development, social development, and environmental protection [28]. Sustainable development is mostly interpreted and understood in the context of the triple bottom line approach as indicated in Figure 2 below. The SD theory, made popular through practice, is inseparable from relevant policies implementation [29] and may involve the assessment of stakeholder perceptions.

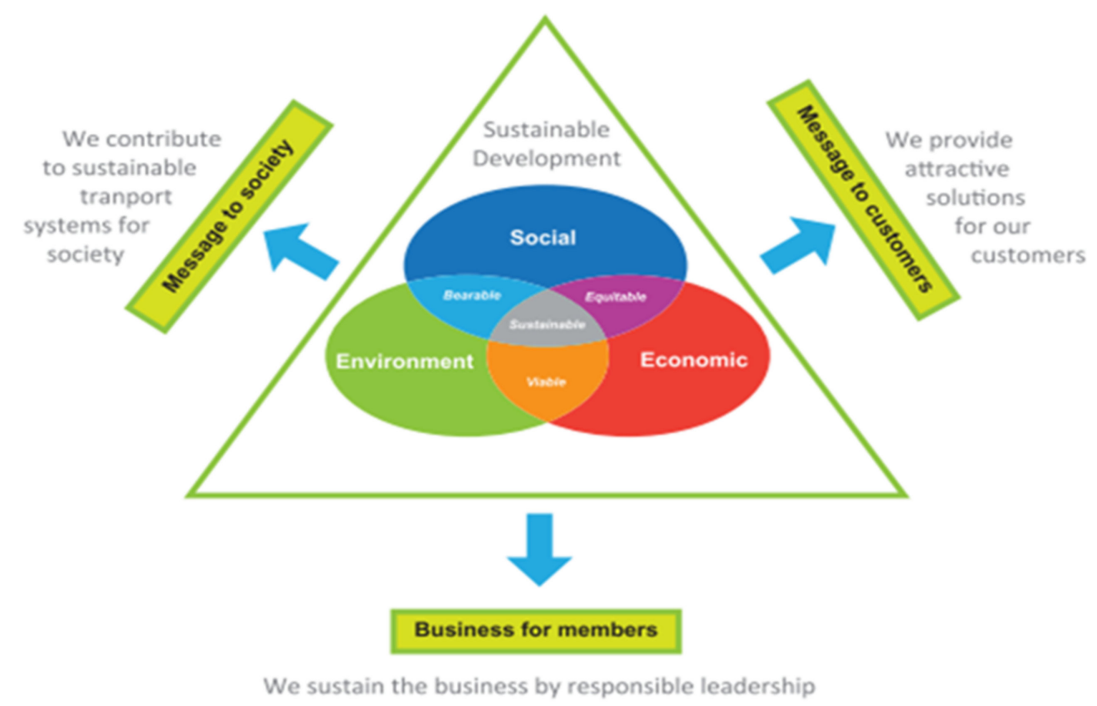

Figure 2. Percentages of $\mathrm{CO}_{2}$ release in the transport sector. Source: International transport forum, Transport greenhouse gas emission 2010, [28].

The need for sustainability has emerged in this context [30] and the concept of sustainability, popularized in recent years, is unquestionably increasingly perceived as a necessary tool for understanding the social, economic, and environmental consequences linked to projects and project management [31].

However, some researchers approach sustainability differently and consider it to be composed of several other dimensions [26] with other dimensions or principles considered such as risk reduction, stakeholder, and accountability [32].

Environmental sustainability impacts to transport are geared towards attaining a reduction in local atmospheric pollution, global warming, negative impact on plants and animals, the impact of solid waste disposal on the environment, etc. [8]. Socially, sustainable urban transportation is concerned with delivering satisfactory access to transport with the objective of curtailing social exclusion, and progresses an individual's quality of life $[8,33]$. The social aspects can encompass corporate governance, human capital development, human rights, labor practices, relation with employees, and working conditions, safety, engagement of stakeholders, and decent work. The economic aspect involves return on investment, business agility, risk reduction, risk reduction, cost management, honest price, and service, project reporting, and investment evaluation. It has been clearly documented that in the contemporary economy, transport is pivotal due to its effects on social, and economic development [34].

This implies, therefore, that a properly functioning, and modern transport system leads to sustainable development as all other sectors such as power, industry, health, and 
construction at one-point need to depend on transport for their delivery. In fact, the greatest priority of sustainable transport is to ensure effective and efficient mobility of goods and people, while at the same time contributing to the realization of economic, social, and environmental sustainability dimensions as shown in Figure 2. The International Union of Railways (UIC) declaration and indicators of sustainable mobility and transport provide the areas in which railways are contributing to sustainability. Spill-over sustainability contributions are not mentioned.

Railways certainly have a crucial role in a sustainable, safer, and greener evolution of the transport system [34-36]. Light rails can play a significant role to reduce the environmental impact of any city through providing efficient and effective transport with low environmental consequences, which in the end helps to fashion a more sustainable approach to transport.

Railways as the backbone of sustainable transport make strong connections to a number of the SDGs and supporting targets, notably; energy efficiency (Goal 7), resilient infrastructure (Goal 9) and access to sustainable transport (Goal 11) [37], resilience to climate-related hazards (Goal 13), and promote environmentally sound technologies and multi-stakeholder partnerships (Goal 17) [38].

According to the international transport forum, Transport greenhouse gas emission 2010, within the transport sector, energy consumption and therefore $\mathrm{CO}_{2}$ emissions are dominated by road, followed by aviation and shipping. Rail accounts for $2 \%$ of $\mathrm{CO}_{2}$ emissions within the transport sector as indicated in Figure 3 below. This, therefore, implies that railways are the good performers towards environmental sustainability in the transport sector.
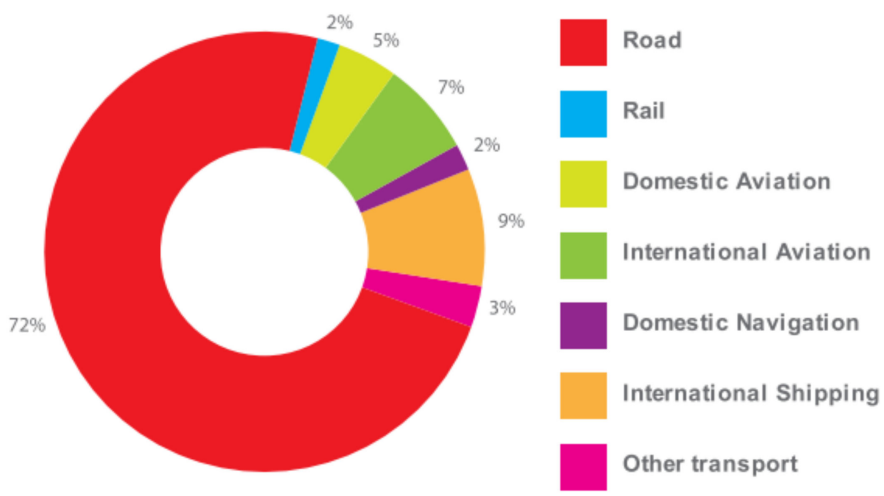

Figure 3. Percentages of $\mathrm{CO}_{2}$ release in the transport sector. Source: International transport forum, Transport greenhouse gas emission 2010, [28].

Transport carbon dioxide emissions 2008.

This claim is further verified by data collected from $28 \mathrm{EU}$ nations and was published in 2014, The collected data as indicated in Figure 4 below projects railway transport as the best performer contributing, only 7 million tonnes of $\mathrm{CO}_{2}$ emissions with road transport leading at 833.3 million tonnes.

In discussing the findings of their study, [40] suggest that the construction of Urban Rail Transit has played an important role in realizing great-leap-forward development of economy and improving the urban economic structure and has become the source impetus for fueling urban economic growth. They further describe in detail three effects as (1) it leads the transformation of economic development way, (2) construction provides broad development space for environmental protection industry, and (3) construction improves the city's soft power. The need now is to quantify some of these effects that this paper intends to perform as well. Alade et al. [8] asserts that excluding the economic profits, the environmental and social development benefits are also derived from rail system ventures. The authors of this paper, therefore, believe that apart from the targets of railways that 
include: climate protection, energy efficiency, exhaust emissions, noise, and vibrations [41], railways have much to offer in support of sustainable development.

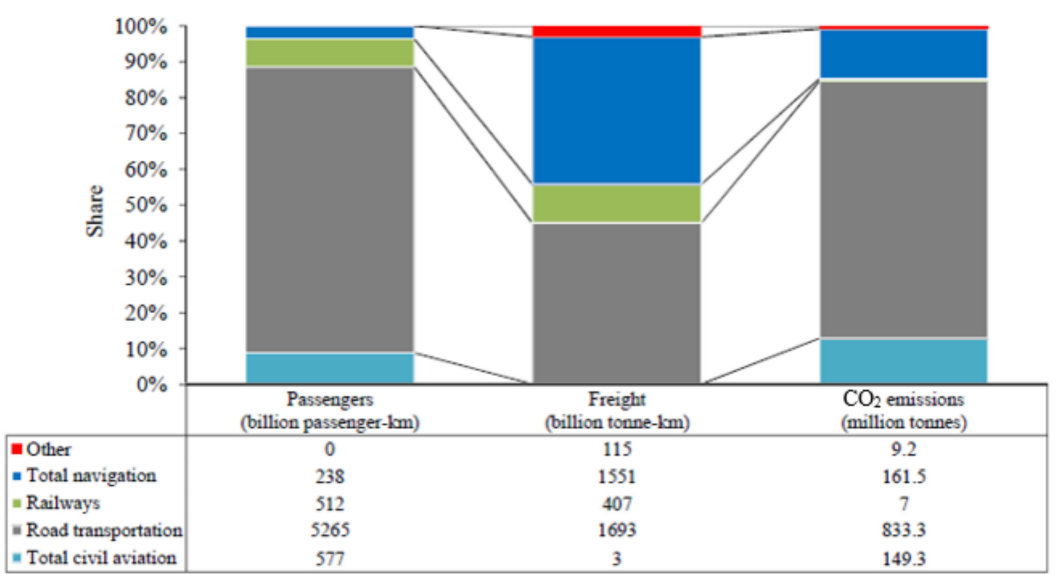

Figure 4. Comparison of transport performance by mode and respective $\mathrm{CO}_{2}$ emissions in EU-28 countries (EC, 2014). Source: [39].

\section{Materials and Methods Methods}

Research methods are the techniques that involve the use of developed research instruments and/or tools that researchers use while carrying out the study to gain feedback from respondents [42]. This study has been conducted based on extensive collection of data, adopting [43] a quantitative methods pproach to assess the contributions of light rail in the sustainable development of Addis Ababa city below (See Figure 5 below).

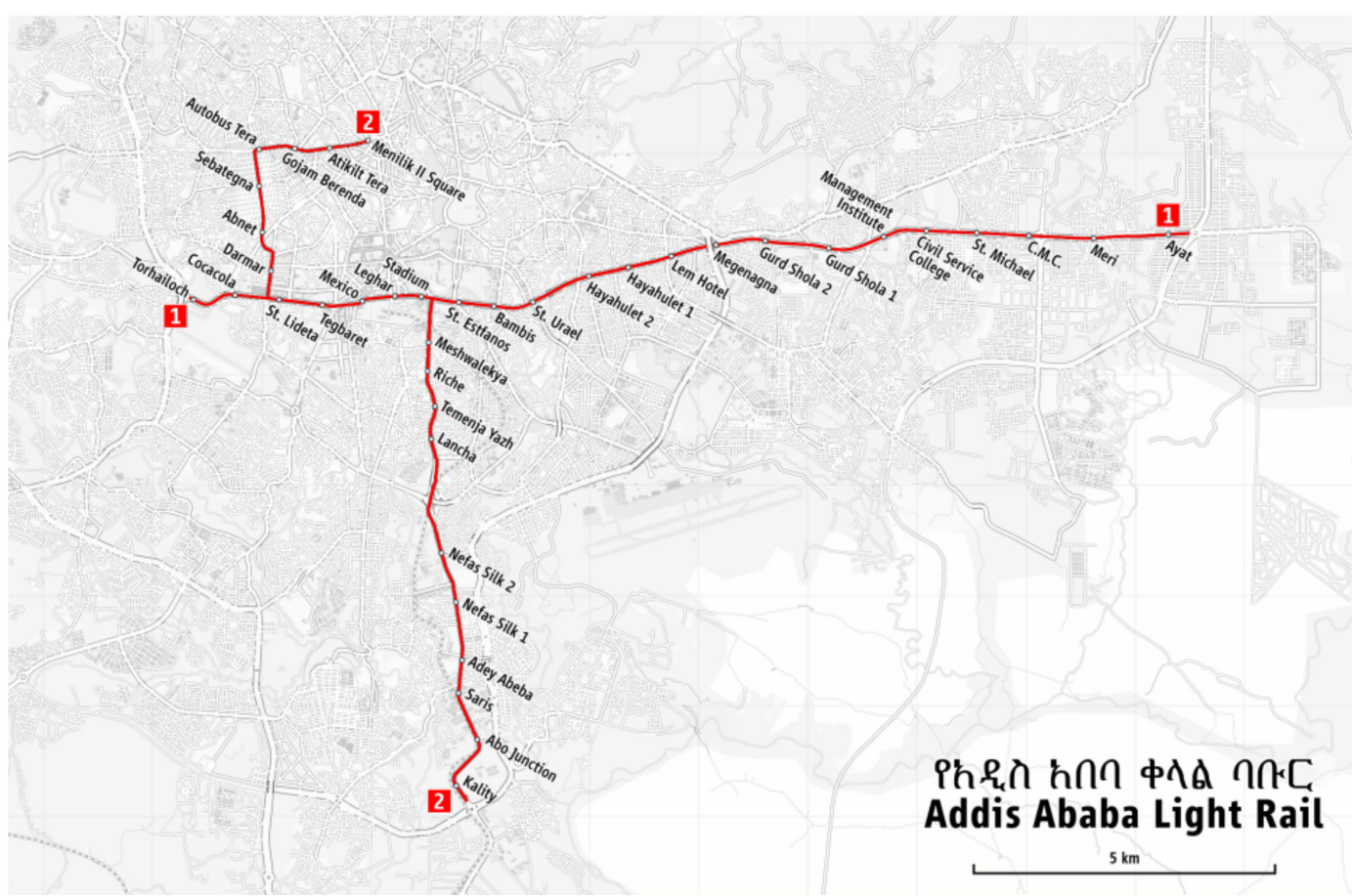

Figure 5. Location map of Addis Ababa RLT (Source [44]).

Recent research works of this nature, although in a different field, had been conducted before following a quantitative approach by [15], which validates that using a quantitative approach in this study will increase the seriousness of understanding sustainability contributions of light rails. The topic of the study suggests that it follows a case study approach, 
which is an appropriate research strategy for complex phenomena that cannot be studied outside their context and for in-depth investigation [45].

The variables/aspects of the study were developed and customized basing on the sustainability model developed by [46] and was provided to the researchers upon request. During the research period, several data collection methods where used to complement the process, and these included document analysis and interviews. Quantitative data collection was mainly done by the use of a survey questionnaire. The survey utilized a Likert scale consisting of five aspects in each one of the sustainability dimensions on a 5-point Likert scale ranging [15] from 1 (strongly agree) to 5 (strongly disagree). In this same approach, the two components of the sustainability definition were also ranged, and perceived importance was analyzed. A direct formulation of the contribution of AA-LRT in forms of respective dimensions was also ranged on the same scale and studied.

The collected data was used to examine how the LRT contributes to transport sustainability through linking the respondents' feedback to pre-determined variables. Other data sources utilized included Ethiopia population census data, government statistical reports, journal papers, and other publications. A total of 393 respondents, mainly passengers found at railway stations and inside trains during transit and staff of ERC, residents found on bus and taxi stages, and Addis Ababa university students and staff participated in this study. A draft questionnaire was shared with one professor and two doctors (Ph.D.), all of who are teaching staff at the African railway center of excellence, Addis Ababa University, and their insights that guided in the development of a final questionnaire, which was administered to respondents both physically in hard copies and through an online survey using Google forms. A section of Addis Ababa university students who use the AA-RLT daily was part of the respondents and these could either pick the questionnaire and return it filled within a week or had to fill it at the university at their convenience. The questionnaire was constructed based on the three pillars of sustainability with respective constructs.

Convenience and purposive sampling were used on transport passengers in Addis Ababa including some RLT experts who work with the ERC. Data collected from the respondents was analyzed using IBM SPSS 25 statistical analysis software to generate descriptive, inferential, and multivariate statistical outputs that are presented in the tables and figures in this study.

The validity and reliability of the tools used in this study were ensured through the following ways; first quantitatively, the questionnaire was tested for validity using Cronbach's Alpha measure of the scale of reliability as well as giving it to university staff for corrections. Reliability of 0.85 (Cronbach's alpha) value was esteemed as acceptable. This was calculated on all survey items for this study. Qualitatively, by asking consent from the respondents for data provision, this ensured that the provided data had an acceptable degree of accuracy and acceptable.

Some of the demographic information that was collected and examined during the study include; location of the respondent in Addis Ababa (residence), gender, duration of stay in Addis Ababa, transport medium used in Addis Ababa, and category of service provision/employment. The location of respondents was scattered amongst Addis Ababa communities revealing no important pattern. The table below summarizes necessary demographic characteristics of the study.

From Table 4, as shown below, regarding descriptive statistics, it can be seen that a bigger percentage of the respondents were male $(56.50 \%)$ compared to female $(43.50 \%)$. The split between the transport medium used while in Addis Ababa reveals that the biggest percentage of respondents at $49.60 \%$ were AA-RLT users, while those who use private means were the lowest at $7.90 \%$. It can be deduced that the results of the study are reliable as the biggest percentage of respondents really use the LRT most often. In addition, most of the respondents had lived in Addis Ababa for more than 5 years, implying that they are aware of happenings around Ethiopia's main city. 
Table 4. Demographic characteristics of the respondents.

\begin{tabular}{cccc}
\hline Variable & Category & Frequency & Percentage \\
\hline \multirow{3}{*}{ Gender } & Male & 222 & 56.50 \\
& Female & 171 & 43.50 \\
& Total & 393 & 100.0 \\
\hline & $1-5$ years & 78 & 20.10 \\
Duration of stay in Addis & $6-10$ years & 68 & 17.30 \\
Ababa & $11-15$ years & 76 & 19.30 \\
& $16-20$ years & 72 & 18.30 \\
& $21-25$ years & 98 & 24.90 \\
& Total & 393 & 100.0 \\
\hline Location in Addis Ababa: & & & \\
\hline & Bus & 98 & 24.9 \\
Transport medium used & Light rail transit & 195 & 49.60 \\
while in Addis Ababa & Taxi & 69 & 17.60 \\
& Private means & 31 & 7.90 \\
& Total & 393 & 100.0 \\
\hline & Government worker & 80 & 20.40 \\
Category of current service & Non-government worker & 72 & 18.30 \\
provision/employment & Self-employed & 86 & 21.90 \\
& Student & 155 & 39.40 \\
& Total & 393 & 100.0 \\
\hline & Total & 393 & 100.0 \\
\hline
\end{tabular}

\section{Data Analysis and Results}

The results and analysis of the study have shown that the economic sustainability dimension is perceived to be addressed more than the social and environmental sustainability dimension. Many research studies have found out that the aspects of economic sustainability are considered more since many investors focus on regaining their capital investments and profits at the expense of other sustainability dimensions. This is again evidenced in the findings and analysis of this study. Some of the aspects considered in this are positively related in that when one aspect is being addressed, another aspect is being addressed in the same way and vice versa. In fact, it should be noted that sustainability is wide, and striking a balance amongst all the three dimensions cannot be easily achieved, but is a necessity for achieving the intended sustainability goals. The closeness in some of the aspects within the same dimension gives hope in improving sustainability.

\subsection{Economic Sustainability}

Five constructs of transportation economic sustainability were adopted for the study and included in the questionnaire to the respondents. These constructs included AA-LRT, which provides fair traveling prices compared to other modes of transport in the city (aspect 1); AA-LRT, which offers an honest transport service compared to road transport means (aspect 2); the introduction of AA-LRT, which led to decreased traffic congestion and delays in Addis Ababa (aspect 3); AA-LRT, which releases periodical project reports (profit) to the public and relevant authorities (aspect 4); and AA-LRT, which has direct (financial) benefits to the residents and authorities of Addis Ababa (aspect 5).

From the data collected from respondents about the perceived importance of the economic sustainability dimension, the first level of strongly agree had a percentage weighted average of $43.36 \%$, which is followed by an agree level with $29.2 \%$, then followed by the neutral level on $15.6 \%$. The disagree and strongly disagree levels become last on an average percentage of $8.56 \%$ and $2.74 \%$. The above average percentages of the levels indicate that many respondents accept the fact that AA-LRT is performing well via the economic sustainability aspects presented in the study. 
Considering the individual aspects of economic sustainability dimension, in Figure 6 below, the aspect of introduction of AA-LRT led to decreased traffic congestion and delays in Addis Ababa had the largest percentage (49.9\%) in level 1, implying that the surveyed city dwellers appreciate the reduced traffic congestion in the city due to the introduction of the light rail. Again, considering level 2, the aspect of AA-LRT releasing periodical project reports (profit) to the public and relevant authorities and having the largest percentage (34.4\%), implies that respondents agree that the light rail performance reports are transmitted to relevant authorities. In the neutrality group, that is level 3, the aspect of AA-LRT has direct (financial) benefits to residents and authorities of Addis Ababa city, which had the highest percentage (17.3\%) among selected aspects. The evaluated respondent's neutrality may be attributed to the fact that some of them use several means of transport.

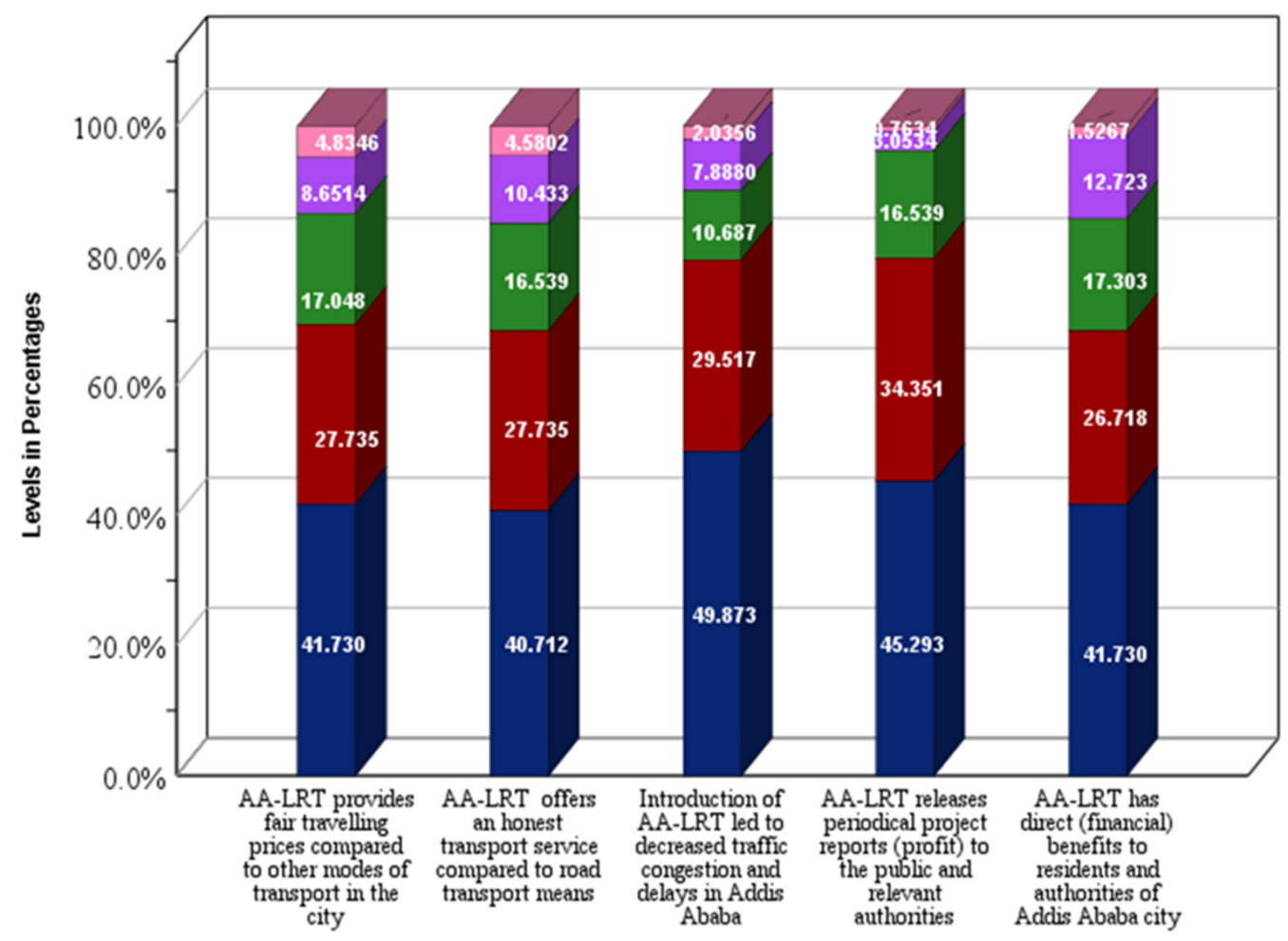

Levels

Strongly disagree

Disagree

Neutral

Agree

Strongly agree

Figure 6. Category of the perceived importance of economic sustainability aspects.

It is surprising to note that the same aspect has the highest percentage $(12.7 \%)$ for level 4 of disagree. The fact that light rail developments have financial benefits either directly or indirectly may not be visible to everyone and perhaps, this may be the reason why a big cluster of the respondents do not seem to realize the direct financial benefits from the AA-LRT. In level 5 of strongly disagree, the aspect of AA-LRT provides fair traveling prices compared to other modes of transport in the city, and has the highest percentage (4.8\%) across evaluated respondents. This aspect considers the prices of AA-LRT in relation to other available transport means in the city. The price provided by the light rail services is uniform, whereby travelers who get off from a near station are made to pay the same money as those going to a far station, implying that short- and far-distance travelers are charged the same. This is not the case with other means, presenting a situation of fairness for short-distance travelers. The findings from the economic sustainability analysis help reinforce economic theories [8] which propose computing transport services prices based on competition methods. Providing user affordable charges increases the perception of economic sustainability from users. They also present fresh perspective on variables within the economic [4] aspects of transport sustainable development. 
A Pearson product-moment correlation was also conducted to examine the degree of relationships between the above selected aspects of the economic sustainability dimension. AA-LRT provides fair traveling prices compared to other modes of transport in the city and was more strongly positively related, as AA-LRT offers an honest transport service compared to road transport means, $\mathrm{r}(391)=0.558,(p<0.001)$. AA-LRT also releases periodical project reports (profit) to the public and relevant authorities, which was the least strongly positively related $\mathrm{r}(391)=0.208,(p<0.001)$. A complete list of examined correlations is presented in Table 5 below.

Table 5. Pearson's moment-product correlation between economic sustainability aspects.

Correlation for AA-LRT Provides Fair Travelling Prices Compared to Other Modes of Transport in the City (N = 393) (Amongst Economic Sustainability Aspects)

\begin{tabular}{|c|c|c|c|c|}
\hline & $\begin{array}{c}\text { AA-LRT Offers an } \\
\text { Honest Transport } \\
\text { Service Compared to } \\
\text { Road Transport } \\
\text { Means }\end{array}$ & $\begin{array}{l}\text { The Introduction of } \\
\text { AA-LRT Led to } \\
\text { Decreased Traffic } \\
\text { Congestion and Delays } \\
\text { in Addis Ababa }\end{array}$ & $\begin{array}{l}\text { AA-LRT Releases } \\
\text { Periodical Project } \\
\text { Reports (Profit) to the } \\
\text { Public and Relevant } \\
\text { Authorities }\end{array}$ & $\begin{array}{c}\text { AA-LRT Has Direct } \\
\text { (Financial) Benefits to } \\
\text { Residents and } \\
\text { Authorities of Addis } \\
\text { Ababa City }\end{array}$ \\
\hline $\begin{array}{l}\text { AA-LRT provides fair } \\
\text { travelling prices compared } \\
\text { to other modes of transport } \\
\text { in the city }\end{array}$ & $0.558^{* *}$ & $0.250^{* *}$ & $0.208^{* *}$ & $0.297^{* *}$ \\
\hline $\begin{array}{l}\text { AA-LRT offers an honest } \\
\text { transport service compared } \\
\text { to road transport means }\end{array}$ & 1 & $0.394^{* *}$ & $0.245^{* *}$ & $0.341^{* *}$ \\
\hline $\begin{array}{l}\text { The introduction of } \\
\text { AA-LRT led to decreased } \\
\text { traffic congestion and } \\
\text { delays in Addis Ababa }\end{array}$ & & 1 & $0.281^{* *}$ & $0.546^{* *}$ \\
\hline $\begin{array}{l}\text { AA-LRT releases periodical } \\
\text { project reports (profit) to } \\
\text { the public and relevant } \\
\text { authorities }\end{array}$ & & & 1 & $0.367^{* *}$ \\
\hline
\end{tabular}

Note. ${ }^{* *}$ Correlation is significant at the 0.01 level, Sig. (2-tailed).

The correlation relationship, which is positive and significant, particularly indicates that as one aspect is perceived to be addressed better, so is the other aspect also addressed better, rather in the same way. For example, the better AA-LRT provides fair travelling prices compared to other modes of transport in the city, the more it will release periodical project reports (profit) to the public and relevant authorities.

\subsection{Environmental Sustainability}

The five transportation environmental sustainability aspects considered are: the establishment of the AA-LRT, which led to decreased transport air pollution levels in Addis Ababa; AALRT, which led to energy saving through the use of little energy for great haul, experiencing a great positive change in the air quality due to the lowered level of exhaust emission due to AA LRT service; AA-LRT, which led to a reduction in transport noise and vibrations in the Addis Ababa; and AA-LRT management, which always gives out environmental laws and regulations and publishes environmental reports.

Based on the data collected from respondents about the perceived importance of the environmental sustainability dimension aspects, the first level of strongly agree (level 1) had a percentage weighted average of $41.96 \%$. It was then closely followed by agree (level 2) with a percentage average of $32.34 \%$. The average percentage of the neutral level (level 3 ) is $15.16 \%$. The average percentage of those who disagree (level 4 ) is 7.5 and strongly disagree (level 5) comes last with an average percentage of $3.02 \%$. These average percentages of each level indicate that many respondents who participated in this study 
believe that AA-LRT does well in fulfilling the considered aspects of the environmental sustainability dimension.

Considering each of the aspects of environmental sustainability dimension, as illustrated in Figure 7 below, the aspect of the establishment of the AA-LRT, which led to decreased transport air pollution levels in Addis Ababa had the highest percentage (48.3\%) in the level 1 category. This aspect considers the pollution levels from motor vehicle movement within the city but most especially in the areas where the light rails pass, also considered that respondents felt a sense of freshness in the air quality due to the introduction of AA-LRT. In the second position for the highest percentage of level two category is the aspect of AA-LRT management, which always gives out environmental laws and regulations and publishes environmental reports, at (39.4\%). With the clear regulations in form of signposts and stickers commonly found on railway stations and inside the train, respondents feel it is agreeable to note that environmental rules and regulations are well communicated. In the third category of neutral (level 3) respondents about aspects, AALRT led to energy saving through the use of little energy for great haul aspect, which has the highest percentage (20.9\%). Most likely, in this category, many respondents find it difficult to relate the consumption of electricity by trains and compare this with fuel (diesel) consumption. Level 4 has the aspect of AA-LRT, which has led to a reduction in transport noise and vibrations in the Addis Ababa, with the highest percentage (11.5\%). The findings from environmental sustainability analysis supports theories of sustainability that attempt to prioritize and integrate [47] environmental concerns, perceptions, and problems into sustainable development.

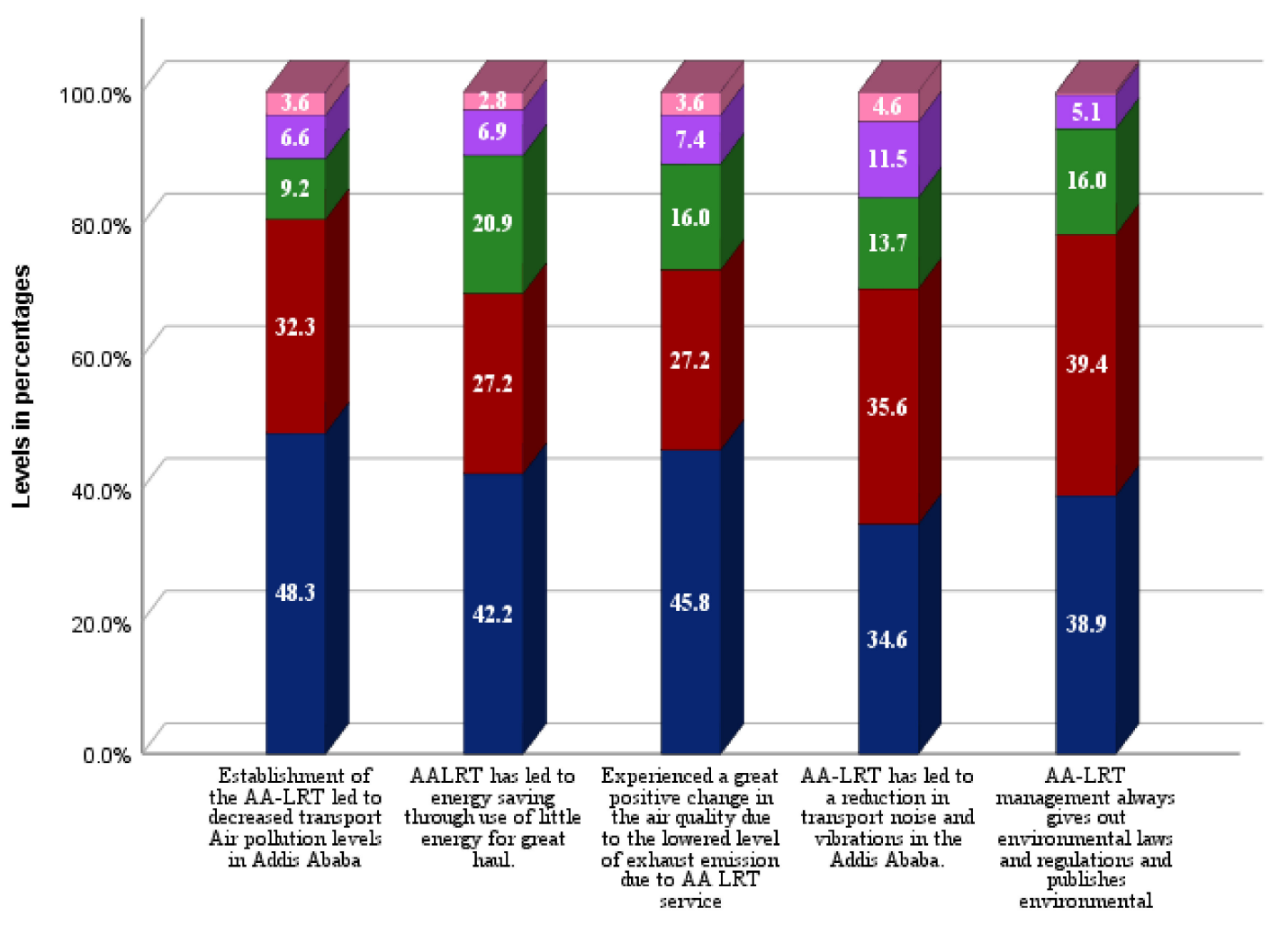

Levels

Strongly disagree Disagree

Neutral Agree Strongly agree

Figure 7. Category of perceived importance of environmental sustainability aspects.

Coincidentally, the same aspect has the highest percentage (4.6\%) amongst the level 5 subdivision. In the analysis of the last two levels mentioned above, many respondents have a negative belief about a reduction in noise and vibration due to the introduction and 
operation of the train in the city. This is evident to the extent that even during the survey, great noise would be heard whenever the train was passing by.

Pearson correlation conducted between the considered aspects of environmental sustainability dimension to measure the strength and direction of relationship amongst the aspects, which revealed a very strong positive significant relationship, $\mathrm{r}(391)=0.874$, $(p<0.001)$. This was in consideration of the aspect, establishment of the AA-LRT, which led to decreased transport Air pollution levels in Addis Ababa in relation to the aspect, experienced a great positive change in the air quality due to the lowered level of exhaust emission due to AA LRT service. This is illustrated in Table 6 below.

Table 6. Pearson's moment-product correlation between environmental sustainability aspects.

\begin{tabular}{|c|c|c|c|c|}
\hline \multicolumn{5}{|c|}{$\begin{array}{l}\text { Correlation for Establishment of the AA-LRT Led to Decreased Transport Air Pollution Levels in Addis Ababa (N = 393) } \\
\text { (Amongst Environmental Aspects) }\end{array}$} \\
\hline & $\begin{array}{l}\text { AALRT Has Led } \\
\text { to Energy Saving } \\
\text { through Use of } \\
\text { Little Energy for } \\
\text { Great Haul }\end{array}$ & $\begin{array}{l}\text { Experienced a Great } \\
\text { Positive Change in the } \\
\text { Air Quality Due to the } \\
\text { Lowered Level of } \\
\text { Exhaust Emission Due } \\
\text { to AA LRT Service }\end{array}$ & $\begin{array}{l}\text { AA-LRT Has Led to } \\
\text { a Reduction in } \\
\text { Transport Noise } \\
\text { and Vibrations in } \\
\text { Addis Ababa }\end{array}$ & $\begin{array}{c}\text { AA-LRT Management } \\
\text { Always Gives out } \\
\text { Environmental Laws } \\
\text { and Regulations and } \\
\text { Publishes } \\
\text { Environmental Reports }\end{array}$ \\
\hline $\begin{array}{l}\text { The establishment of the } \\
\text { AA-LRT led to decreased } \\
\text { transport Air pollution levels in } \\
\text { Addis Ababa }\end{array}$ & $0.507^{* *}$ & $0.874^{* *}$ & 0.771 ** & $0.569 * *$ \\
\hline $\begin{array}{l}\text { AALRT has led to energy saving } \\
\text { through the use of little energy } \\
\text { for great haul. }\end{array}$ & 1 & $0.475^{* *}$ & $0.440^{* *}$ & $0.377^{* *}$ \\
\hline $\begin{array}{l}\text { Experienced a great positive } \\
\text { change in the air quality due to } \\
\text { the lowered level of exhaust } \\
\text { emission due to AA LRT service }\end{array}$ & & 1 & $0.805^{* *}$ & $0.590 * *$ \\
\hline $\begin{array}{l}\text { AA-LRT has led to a reduction in } \\
\text { transport noise and vibrations in } \\
\text { the Addis Ababa. }\end{array}$ & & & 1 & $0.645 * *$ \\
\hline
\end{tabular}

Note. ${ }^{* *}$ Correlation is significant at the 0.01 level, Sig. (2-tailed).

\subsection{Social Sustainability}

The assessment of transportation social sustainability was composed of five variables, namely: AA-LRT, which is a safe and health-wise mode of transport compared to other transport modes in Addis Ababa; AA-LRT, which offers assistance to passengers with particular mobility needs such as the disabled to use the train; AA-LRT which offers equal opportunities and diversity to all residents of Addis Ababa; AA-LRT, which offers a reliable and convenient transport mode for business activities in the city; and AA-LRT, which offers decent work and labor practices for the whole population.

Considering the attained feedback from the survey questionnaire put across to respondents about the perceived importance of the social sustainability dimension aspects, as shown in Figure 8 below, the first level of strongly agree (level 1), with a percentage weighted average of $37.34 \%$. This was then followed by agree (level 2) with a percentage average of $29.26 \%$. The neutral level (level 3) had an average percentage of $21.6 \%$. Disagree (level 4) achieved a percentage average of $7.16 \%$ with the strongly disagree (level 5) category in the last position with an average percentage of $4.52 \%$. The averages of the percentages for each level indicate that many respondents who participated in this study believe that AA-LRT improves the social status of the city dwellers. 


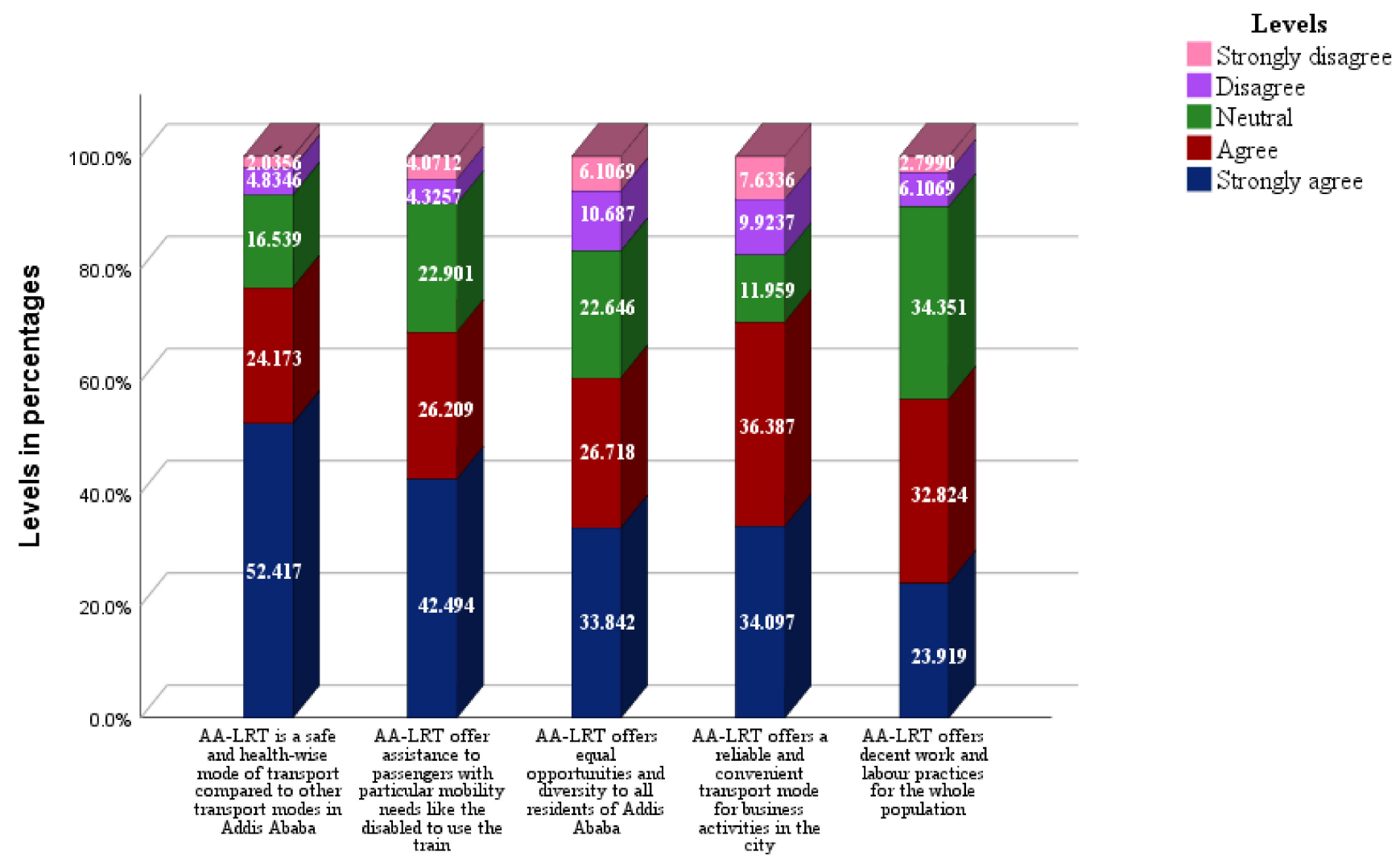

Figure 8. Category of perceived importance of social sustainability aspects.

On the performance of individual aspects, as can be seen in Figure 8 above, the aspect of AA-LRT is a safe and health-wise mode of transport compared to other transport modes in Addis Ababa, achieving the highest percentage (52.42\%) across the survey responses in the social sustainability dimension for level 1 . Even though passengers flood the trains to the extent that others move while standing, respondents have an admirable sense of safety when they use the train. This can be attributed to the fact that fewer accidents have occurred during the operational period of the train since its introduction compared to motor vehicles. The aspect of AA-LRT offers a reliable and convenient transport mode for business activities in the city achieved the highest percentage (36.4\%) for level 2 . It is well known that the movements of the train are on a timetable with its dedicated route that offers minimal interruption in train movement. This means that business movements can be scheduled well and on time, thus leading to many respondents agreeing that business activities, especially movements, are well supported by the train. The aspect of AA-LRT that offers decent work and labor practices for the whole population has the highest percentage $(34.45 \%)$ amongst level 3 items. Many respondents came through with a neutrality stand on this category, most likely due to the fact that many are not employed by the rail company, so it is hard for them to analyze this properly. Considering level 4 items, a great percentage $(10.7 \%)$ responded to the aspect of AA-LRT offering equal opportunities and diversity to all residents of Addis Ababa. This level of disagreement is surprising and may be based on how easy one can get employed with the LRT operations organization. The highest percentage $(7.6 \%)$ was dedicated to the aspect of AA-LRT offering a reliable and convenient transport mode for business activities in the city. While the same aspect scored high in level 2, it coincidently scores high again in level 5. Some of those who conduct business want to catch the available means of transport instantly and the fact that the train may not be available all the time may hinder their business dealings. The results of the analysis point to a more holistic, integrated, and strategic approach towards social sustainability [48], performance, and a requirement to improve social variables, which are known to be weak in many sustainability studies. 
Pearson's correlation was conducted between the aspects of social sustainability dimension as well, as presented in Table 7 below. The results show that there exists a strong positive significant relationship, $\mathrm{r}(391)=0.423,(p<0.001)$ of AA-LRT is a safe and health-wise mode of transport compared to other transport modes in Addis Ababa in relation to AA-LRT, which offers assistance to passengers with particular mobility need such as the disabled to use the train. As one of the aspects is better addressed, so is the other aspect addressed as well.

Table 7. Pearson's moment-product correlation between social sustainability aspects.

Correlation for Establishment of the AA-LRT Led to Decreased Transport Air Pollution Levels in Addis Ababa (N = 393) (Amongst Social Aspects)

\begin{tabular}{|c|c|c|c|c|}
\hline & $\begin{array}{l}\text { AA-LRT Offer Assistance } \\
\text { to Passengers with } \\
\text { Particular Mobility } \\
\text { Needs Like the Disabled } \\
\text { to Use the Train }\end{array}$ & $\begin{array}{c}\text { AA-LRT Offers } \\
\text { Equal Opportunities } \\
\text { and Diversity to All } \\
\text { Residents of Addis } \\
\text { Ababa }\end{array}$ & $\begin{array}{l}\text { AA-LRT Offers a } \\
\text { Reliable and } \\
\text { Convenient Transport } \\
\text { Mode for Business } \\
\text { Activities in the City }\end{array}$ & $\begin{array}{l}\text { AA-LRT Offers } \\
\text { Decent Work and } \\
\text { Labour Practices } \\
\text { for the Whole } \\
\text { Population }\end{array}$ \\
\hline $\begin{array}{l}\text { AA-LRT is a safe and } \\
\text { health-wise mode of transport } \\
\text { compared to other transport } \\
\text { modes in Addis Ababa }\end{array}$ & $0.423^{* *}$ & $0.396^{* *}$ & $0.337^{* *}$ & $0.255^{* *}$ \\
\hline $\begin{array}{l}\text { AA-LRT offer assistance to } \\
\text { passengers with particular } \\
\text { mobility needs like the } \\
\text { disabled to use the train }\end{array}$ & 1 & $0.498^{* *}$ & $0.315^{* *}$ & $0.314^{* *}$ \\
\hline $\begin{array}{l}\text { AA-LRT offers equal } \\
\text { opportunities and diversity to } \\
\text { all residents of Addis Ababa }\end{array}$ & & 1 & $0.419 * *$ & 0.302 ** \\
\hline $\begin{array}{l}\text { AA-LRT offers a reliable and } \\
\text { convenient transport mode for } \\
\text { business activities in the city }\end{array}$ & & & 1 & 0.238 ** \\
\hline
\end{tabular}

Note. ${ }^{* *}$ Correlation is significant at the 0.01 level, Sig. (2-tailed).

\subsection{Sustainability Definition and Dimensions}

The widely considered definition of sustainability, as coined by the Brundtland report, was related to the operations of AA-LRT and aspects developed from the definition, as seen in Figure 9 below. The sustainability definition comprises of two major development components: 1 . meeting the needs of the present and; 2 . prospects within an ability of future generations to meet their own needs [8,21-23,49-54]. In addition to that, an independent framing was done to seek to know how the respondents perceived the contributions of the AA-LRT on each of the individual dimensions that majorly constitute sustainability without breaking these dimensions into aspects as before. The service level results from the respondents are illustrated in Figure 9 below.

From the sustainability definition, respondents were asked about their views regarding levels on whether AA-LRT meets the current transport needs of Addis Ababa city and the second aspect was if AA-LRT will allow the future to meet their needs. The other three items are contributions of the light rail to the individual sustainability dimensions framed as below. AA-LRT contributes more to the economic development of Addis Ababa city, AA-LRT contributes more to the environmental development of Addis Ababa city and, AA-LRT contributes more to the social development of Addis Ababa city. 


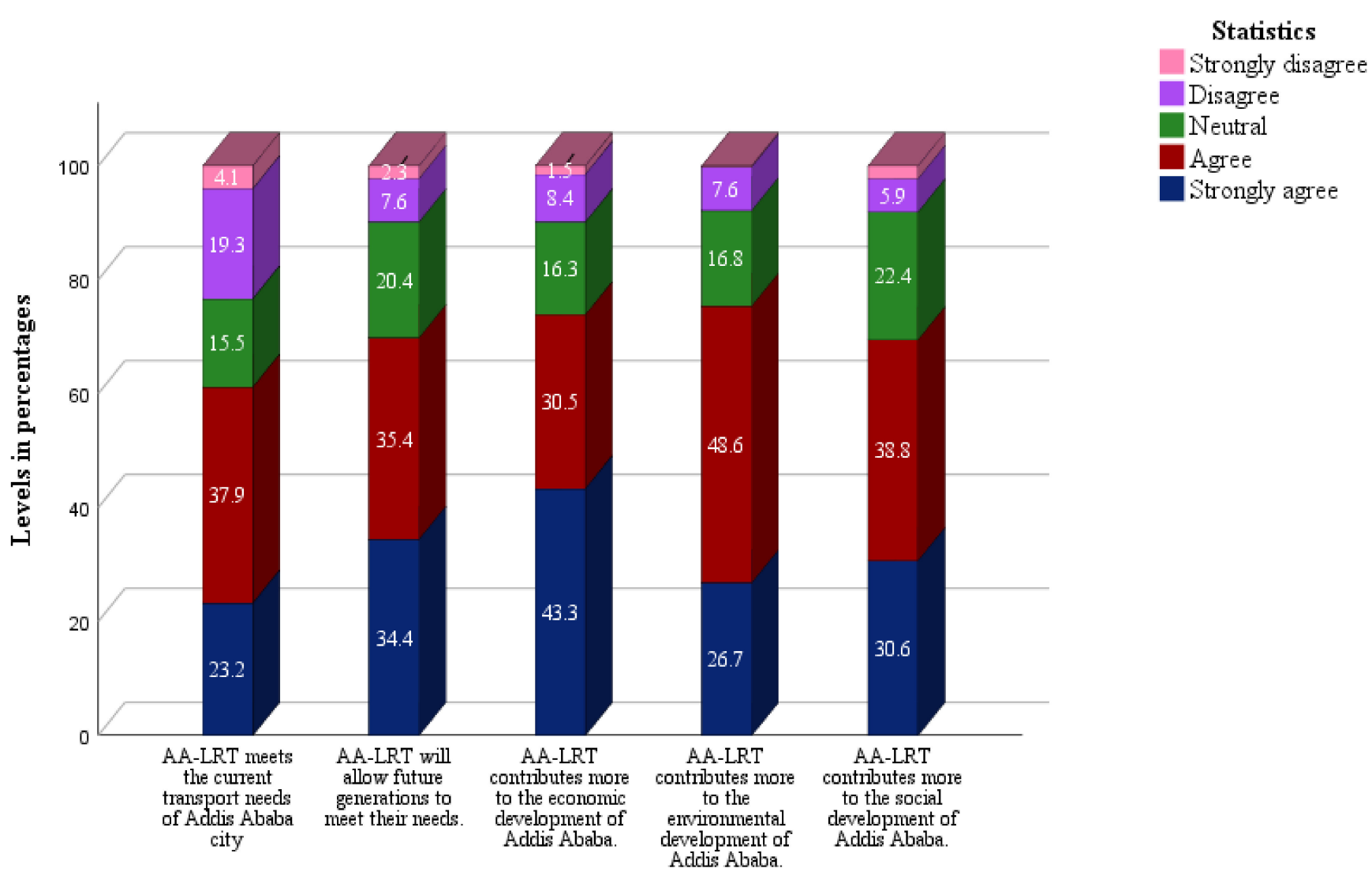

Figure 9. Breakdown on sustainability definition and individual dimensions.

On the first two aspects that are framed from the sustainability definition, level 2 got the highest average percentage (36.65\%). Level 1 becomes second on average percentage $(28.8 \%)$, level 3 average percentage (17.95) became third with the level 4 average percentage $(13.45 \%)$, and level 5 average percentage (3.2\%) in the fourth and fifth position, respectively.

From the affirmation of respondents in the breakdown below, $23.2 \%$ strongly agree (level 1) that AA-LRT meets the current transport needs of Addis Ababa city while allowing future generations to meet their transport needs is at $34.4 \%$. The difference in perceived affirmation can be seen. This clearly shows the transport challenges in Addis Ababa city are enormous and difficulties are still existent, hence transport needs satisfaction is lower. However, all hope is not lost, as many people believe it will enable future generations to meet their needs.

Level 2 perceived importance records many respondents agreeing that AA-LRT meets the transport needs of Addis Ababa city at $37.9 \%$ while enabling future generations to meet their transport needs is at $35.4 \%$. These two levels almost strike a balance in agreement. The combined agreement cohort at $61.1 \%$ for meeting current needs and $69.8 \%$ for meeting future needs show that there is an approach in balance towards fulfilling the components of the sustainability definition. The combined disagreement cohort is at $26.9 \%$ for disagree (level 4) and 6.4\% (level 5) for strongly disagree. This clearly shows that respondents appreciate the contributions being made by AA-LRT in achieving transport sustainability of Addis Ababa.

On individual sustainability dimension aspects analysis, $43.3 \%$ perceive that AA-LRT contributes more to economic sustainability, $26.7 \%$ to environmental sustainability, and $30.6 \%$ to social sustainability, all of which follow under level 1 . However, when levels 1 and 2 are combined, economic sustainability stands at $73.8 \%$, environmental sustainability achieves $75.3 \%$, and social sustainability at $69.4 \%$. This is a manifestation that many respondents perceive that the economic dimension gets more while the social dimension is less valued. The results echo the literature finding of [40], which suggests that light 
rail operations help in promoting the economic development of urban areas. Railways are widely known for their promotion of environmental cleanness by emitting less carbon gaseous products into the environment. It is no doubt that many respondents perceive the environmental dimension for performing well, although not much as the economic dimension. This coincides with the literature finding [28], which concludes that rails perform better environmentally compared to other transport means.

The social sustainability dimension as noted is the least considered dimension of sustainability and is perceived as less important $[24,25,55]$, which corresponds to many prior sustainability studies.

A Pearson correlation conducted between the aspects of the sustainability definition show that there is exists a strong positive significant relationship, $\mathrm{r}(391)=0.500,(p<0.001)$ of AA-LRT meeting the current transport needs of Addis Ababa city in relation to AA-LRT, which will allow the future generations to meet their needs. The results indicate a pure split half balance in addressing these two components of the sustainability definition. Another correlation between the individual dimensions, economic, and environmental was also examined and the results showed a strong positive correlation, $\mathrm{r}(391)=0.403,(p<0.001)$ for environmental sustainability and, $\mathrm{r}(391)=0.485,(p<0.001)$ for social sustainability in relation to economic sustainability. These results also may suggest that environmental and social sustainability are perceived and addressed as almost the same.

\section{Conclusions}

In this paper, we have explored the contributions to the sustainable development of Addis Ababa city brought by the implementation of AA-LRT, which is regarded as one of the avenues of a sustainable urban transport system. We have also examined the perceived importance of the widely accepted sustainability definition components and AA-LRT contribution to separate sustainability dimensions. Through this empirical study, it has been found that AA-LRT has significant direct contributions to the sustainable development of Addis Ababa. By formulating new variables within sustainable transportation and investigating sustainable development based on transport facility user perceptions, the results supplement the available body of knowledge. The findings reveal the perceptions of residents, the first of its kind under this arrangement in Addis Ababa, and can therefore be used as a basis for future planning and RLT developments.

Again, from the analysis of collected data, the findings of the study correlate with prior studies that discovered that economic sustainability is the most well-addressed sustainability dimension [26]. Again, economic sustainability is performing better than social and environmental sustainability dimensions. These last two are almost addressed in the same way.

While the economic sustainability dimension has been found to perform better, thereby positioning AA-LRT to contribute more towards the economic transport sustainability of Addis Ababa, it should not be forgotten that these are weighted perceptions of the respondents. The results of the study therefore do not represent an objective measure of AA-LRT's contributions to sustainable development of Addis Ababa. A logical follow up study is thus deemed necessary through future research to establish objective measures of the considered variables either dimension wise or individually. This will help quantity parameters such as the actual air pollution or noise and vibration reduction levels, the exact reduction in traffic congestion and delays. A further expert evaluation can be done to see how well such findings align with the perceptions. User perceptions are subject to change and this is inevitable due to continued development and population increase over time in such cities. It is therefore suggested that future researchers dive deeper and look into the longitudinal measurements of change in perceptions over time or evaluation of perceptions vs. actual change in relation to the subject matter. The outcomes of these studies will promote the attainment of transport sustainability together with sustainable development.

The findings of the research have numerous important implications to ERC and other urban light rail investment projects in developing cities. 
First, they may guide in informing ERC where it should direct more efforts towards ensuring the sustainability of the AA-RLT in order to ensure a balanced action towards addressing all the three dimensions of sustainability. The study findings will provide additional knowledge to city administrators in developing policies, which can lead to transport sustainability. It may also serve as a reference for future academics, becoming pivotal in the field of sustainable development and RLT areas. These may pick on the study area and discover more research gaps. The findings of this study may also be useful to other developing cities across Africa and Asia that wish to invest in RLT. By looking at these perceptions and knowing how users interpret or assess the services in terms of contributing to sustainable development, they can form a basis to align their operations in a way that they can contribute more to sustainable development in their localities. If LRT projects are looking at improving their public image in regard to sustainability, then these user perceptions are an important starting point for such evaluations.

Due to the varying levels of development, user perception, and people behaviors, the study is generally limited to Ethiopia and Addis Ababa in particular. Among the drawbacks that limited this study was the outset of COVID-19, which cut short the survey time and the number of respondents. A total of 393 respondents were examined in this study, which may be acceptable for academic purposes. However, Addis Ababa city is big with a large population, and AA-LRT passes through different places. The number of respondents can be made larger to include more stakeholders such as city planners, political leaders, city administrators, sustainability development think tanks around the city and more government agencies to ascertain if their sentiments correlate with the findings. Additionally, using questionnaires in research may result into bias especially due to the way the questions are designed, and this can be helped by using a large sample. Another limitation of this research emanates from the study approach and the conceptualization of sustainability and sustainable development. A triple bottom line approach was considered and transport sustainability variables formulated based on the TBL. However, the assessment of sustainability is wide with a collection of many sustainability principles such as considerations by life-cycle orientations, increasing complexity, and long-term/short-term orientations

Light rail operations are relatively new in Africa, the initial capital investment is heavy in terms of financing organizations and governments as well. Such high capital projects need to be well studied to ascertain the sustainability of these establishments. The considered transport sustainability aspects in this study are not the only that can be formulated for study consideration in the sustainability arena.

The narrative that urban rail transportation is always sustainable should not easily be accepted without evidence from research findings. Since railway sustainability is a wide area and LRT is at its infant stage in Africa, prospects for future studies are enormous for example; more sustainability variables under each dimension can be formulated for future case studies basing on the framework of this research, for proposed or under construction LRT projects (see Table 1), how to ensure sustainability of the proposed projects such as the Greater Kampala Light Rail would be a virgin area for researchers in this area, a study on how to ensure sustainability within each project life cycle stage can be conducted, and case studies of project management and project sustainability of RLT in different locations will help in contributing to shrinking the knowledge gap on the two items. Such studies will only serve to buttress the study findings and generate more unknown information if carried out.

Conclusively, the introduction and operation of AA-LRT clearly supports the transport sustainability of Addis Ababa city. The AA-LRT project, being the first of its kind in Ethiopia, has greatly improved transport accessibility and has put Addis Ababa city at the forefront of transport sustainability amongst developing cities across sub-Saharan Africa. 
Author Contributions: Conceptualization, J.S. and M.L.M.; methodology, J.S. and M.L.M.; software, J.S.; formal analysis, J.S.; investigation, J.S.; writing—original draft preparation, J.S.; writingreview and editing, J.S. and M.L.M. All authors have read and agreed to the published version of the manuscript.

Funding: This research received no external funding.

Institutional Review Board Statement: Not applicable.

Informed Consent Statement: Informed consent was obtained from all subjects involved in the study.

Data Availability Statement: All data has been provided through references. Additional data in form of SPSS file can be provided upon request from the authors.

Acknowledgments: The authors sincere appreciation goes to the World Bank (WB) through the African Railway Center of Excellence at Addis Ababa Institute of Technology (AAiT) for the support provided that made this research work a successful one by means of a scholarship to the corresponding author. We also thank AALRT Staff and any other persons who participated in this study.

Conflicts of Interest: The authors declare no conflict of interest.

\section{References}

1. Yañez-Pagans, P.; Martinez, D.; Mitnik, O.A.; Scholl, L.; Vazquez, A. Urban transport systems in Latin America and the Caribbean: Lessons and challenges. Lat. Am. Econ. Rev. 2019, 28, 1-25. [CrossRef]

2. Ryder, A. High speed rail. J. Transp. Geogr. 2012, 22, 303-305. [CrossRef]

3. Alade, T.; Edelenbos, J.; Gianoli, A. Adapting Urban Light-Rail Transport to the African Context: A Process Conducted by Transport Authorities and Chinese Rail Corporations in Addis-Ababa, Abuja, and Lagos. Urban Sci. 2019, 3, 109. [CrossRef]

4. Bamwesigye, D.; Hlavackova, P. Analysis of Sustainable Transport for Smart Cities. Sustainability 2019, 11, 2140. [CrossRef]

5. Simionescu, V.; Silvius, G. Assessing Sustainability of Railway Modernization Projects; A Case Study from Romania. Procedia Comput. Sci. 2016, 100, 458-465. [CrossRef]

6. Valenzuela-Montes, L.M.; Soria-Lara, J.A.; Navarro-Ligero, M.L. Analysing stakeholders' perception of Light Rail Transit as an opportunity to achieve sustainable mobility in Granada (Spain). J. Transp. Geogr. 2016, 54, 391-399. [CrossRef]

7. Ahmed, M.M.A.W.; El Monem, N.A. Sustainable and green transportation for better quality of life case study greater Cairo-Egypt. HBRC J. 2020, 16, 17-37. [CrossRef]

8. Alade, T.; Edelenbos, J.; Gianoli, A. A Sustainable Approach to Innovation Adoption in Light-Rail Transport. Sustainability 2020, 12, 1262. [CrossRef]

9. Gadziński, J.; Radzimski, A. The first rapid tram line in Poland: How has it affected travel behaviours, housing choices and satisfaction, and apartment prices? J. Transp. Geogr. 2016, 54, 451-463. [CrossRef]

10. Olesen, M.; Lassen, C. Rationalities and materialities of light rail scapes. J. Transp. Geogr. 2016, 54, 373-382. [CrossRef]

11. Pojani, D.; Stead, D. Sustainable Urban Transport in the Developing World: Beyond Megacities. Sustainability 2015, 7, 7784-7805. [CrossRef]

12. Alpkokin, P.; Kiremitci, S.T.; Black, J.A.; Cetinavci, S. LRT and street tram policies and implementation in turkish cities. J. Transp. Geogr. 2016, 54, 476-487. [CrossRef]

13. Olesen, M. Framing light rail projects-Case studies from Bergen, Angers and Bern. Case Stud. Transp. Policy 2014, 2, 10-19. [CrossRef]

14. Butlin, J. Our common future. By World commission on environment and development. J. Int. Dev. 1989, 1, 284-287. [CrossRef]

15. Clinning, G.; Marnewick, C. Incorporating sustainability into IT project management. S. Afr. Comput. J. 2017, 29, 1-26. [CrossRef]

16. City strength resilient cities program. Addis Ababa, Ethiopia. In Enhancing Urban Resilience; Global Practice on Social, Urban, Rural and Resilience; The International Bank of Reconstruction and Development/The World Bank Group: Washington, DC, USA, 2015. Available online: www.worldbank.org/urban (accessed on 28 January 2020).

17. Getaw, S.A. Post Completion Sustainability of Ethiopian Railway Project: The Case of Addis Ababa Light Rail Transit Project (AALRTP). Management 2017, 7, 7-28. [CrossRef]

18. Kołoś, A.; Taczanowski, J. The feasibility of introducing light rail systems in medium-sized towns in Central Europe. J. Transp. Geogr. 2016, 54, 400-413. [CrossRef]

19. Blumenfeld, M.; Wemakor, W.; Azzouz, L.; Roberts, C. Developing a new technical strategy for rail infrastructure in low-income Countries in Sub-Saharan Africa and South Asia. Sustainability 2019, 11, 4319. [CrossRef]

20. Grob, L.; Craven, N.; Union, I. Analysis of Regional Differences in Global Rail Projects by Cost, Length and Project stage. Int. Union Railw. 2018, 1-18. Available online: https://uic.org/IMG/pdf/analysis_of_global_rail_infrastructure_investment.pdf (accessed on 3 November 2020).

21. Zuofa, T.; Ochieng, E. Sustainability in Construction Project Delivery: A Study of Experienced Project Managers in Nigeria. Proj. Manag. J. 2017, 47, 44-55. [CrossRef] 
22. Chawla, V.K.; Chanda, A.K.; Angra, S.; Chawla, G.R. The sustainable project management: A review and future possibilities. J. Proj. Manag. 2018, 3, 157-170. [CrossRef]

23. Ibrahim, A.; Iravo, M.; Iravo, M. An assessment of sustainability of donor funded road construction projects in Kenya. J. Humanit. Soc. Sci. 2016, 21, 54-60. [CrossRef]

24. Martens, M.L.; Carvalho, M.M. Key factors of sustainability in project management context: A survey exploring the project managers' perspective. Int. J. Proj. Manag. 2016, 35, 1084-1102. [CrossRef]

25. Martens, M.L.; Carvalho, M.M. Sustainability and Success Variables in the Project Management Context: An Expert Panel. Proj. Manag. J. 2016, 47, 24-43. [CrossRef]

26. Silvius, A.J.G.; Schipper, R.P.J. Sustainability in project management: A literature review and impact analysis. Soc. Bus. 2014, 4 63-96. [CrossRef]

27. Miller, P.B.V. Sustainability and Public Transportation Theory and Analysis. Ph.D. Thesis, University of Calgary, Calgary, AB, Canada, 2014. [CrossRef]

28. Veitch, A.; Schwarz, H. Rail and Sustainable and Development; International Union of Rails (UIC): Paris, France, 2011. Available online: http:/ / temis.documentation.developpement-durable.gouv.fr/docs/Temis/0069/Temis-0069859/19190.pdf (accessed on 16 January 2020).

29. Shi, L.; Han, L.; Yang, F.; Gao, L. The Evolution of Sustainable Development Theory: Types, Goals, and Research Prospects. Sustainability 2019, 11, 7158. [CrossRef]

30. Amiril, A.; Nawawi, A.H.; Takim, R.; Latif, S.N.F.A. Transportation Infrastructure Project Sustainability Factors and Performance. Procedia Soc. Behav. Sci. 2014, 153, 90-98. [CrossRef]

31. Martens, M.L.; Carvalho, M.M. A conceptual framework of sustainability in project management. Int. J. Proj. Manag. 2014, 25, 328-336. [CrossRef]

32. Goedknegt, D.; Silvius, G. The Implementation of Sustainability Principles in Project Management. In Proceedings of the 26th IPMA World Congress, Crete, Greece, 29-31 October 2012; pp. 875-882. Available online: https:/ /www.scirp.org/(S(35 1jmbntvnsjt1aadkozje))/reference/ReferencesPapers.aspx?ReferenceID=1197255 (accessed on 16 January 2020).

33. Litman, T.; Brenman, M.; Consultancy, S.J. A New Social Equity Agenda for Sustainable Transportation; Victoria Transport Policy Institute: Victoria, BC, Canada, 2012.

34. Cruceanu, C. Sustainability of railway transport system-An overview. In Proceedings of the 4th International Conference on Energy Systems, Environment, Entrepreneurship and Innovation (ICESEEI '15), Dubai, United Arab Emirates, 22-24 February 2015; pp. 214-223.

35. Nick, C.; Raimondo, O.; Massimo, C.; Daniele, A. Railways and green growth, why investing in railways leads to a better future. Int. Union Railw. 2015, 1-45. Available online: https://www.fondazionesvilupposostenibile.org/wp-content/uploads/dlm_ uploads/2016/07/Railways-and-Green-Growth.pdf (accessed on 16 December 2020).

36. UK Department for Transport. A time of Unprecedented Change in the Transport System. 2019. Available online: https://assets. publishing.service.gov.uk/government/uploads/system/uploads/attachment_data/file/775077/future_of_mobility.pdf (accessed on 24 February 2020).

37. Department for Transport. Towards a Sustainable Transport System: Supporting Economic Growth in a Low Carbon World. 2007. Available online: www.dft.gov.uk (accessed on 21 January 2020).

38. Craven, N. Railways as the Backbone of Environmentally Sustainable Transport and their Contribution to the Sustainable Development Goals (SDGs). In Proceedings of the Intergovernmental Tenth Regional Environmentally Sustainable Transport. (Est) Forum in Asia, Vientiane, Laos, 14-16 March 2017.

39. Paixão, A. Transition Zones in Railway Tracks: An Experimental and Numerical Study on the Structural Behaviour. Ph.D. Thesis, University of Porto, Porto, Portugal, 2014.

40. Huang, C.F.; Xia, Y. Research on the role of urban rail transit in promoting economic development. Procedia Eng. 2011, 21, 520-525. [CrossRef]

41. UIC; CER. Moving Towards Sustainable Mobility. 2012. Available online: http://www.uic.org/IMG/pdf/pres-strategy.pdf (accessed on 30 February 2020).

42. Almalki, S. Integrating Quantitative and Qualitative Data in Mixed Methods Research—Challenges and Benefits. J. Educ. Learn. 2016, 5, 288. [CrossRef]

43. Chen, X. A Sustainability Analysis on the Wuhan-Guangzhou High-Speed Railway in China. Int. J. Sustain. Transp. 2015, 9, 348-363. [CrossRef]

44. Transit Maps: Official Map: Addis Ababa Light Rail, Ethiopia. 2019. Available online: https://transitmap.net/addis-ababa-lightrail/ (accessed on 13 April 2021).

45. Rasid, S.Z.A.; Ismail, W.K.W.; Mohammad, N.H.; Long, C.S. Assessing Adoption of Project Management Knowledge Areas and Maturity Level: Case Study of a Public Agency in Malaysia. J. Manag. Eng. 2014, 30, 264-271. [CrossRef]

46. Silvius, A.J.G.; Schipper, R. Developing a maturity model for assessing sustainable project management. J. Mod. Proj. Manag. 2015, 3, 16-27. [CrossRef]

47. Jenkins, W. Berkshire Encyclopedia of Sustainability, The Spirit of Sustainability. Berkshire Publishing Group: Great Barrington, MA, USA, 2009; pp. 380-385. 
48. Rezaee, Z. Corporate Sustainability: Theoretical and Integrated Strategic Imperative and Pragmatic Approach. J. Bus. Inq. 2017, 16, 60-87. Available online: http:www.uvu.edu/woodbury/jbi/articles (accessed on 23 January 2020).

49. Oino, G.P.; Towett, G.; Kirui, K.K.; Luvega, C. The dilemma in sustainability of Community-Based projects in Kenya. Glob. J. Adv. Res. 2015, 2, 757-768.

50. Martens, M.L.; de Carvalho, M.M. An exploratory study of sustainability evaluation in project management. Prod. Manag. Dev. 2013, 11, 111-117. [CrossRef]

51. Amasuomo, E.; Hasnain, S.A.; Osanyinlusi, A.Y. Sustainable Development in the Context of Major Infrastructure Projects in United Kingdom. J. Geosci. Environ. Prot. 2015, 3, 44-55. [CrossRef]

52. Mensah, J. Sustainable development: Meaning, history, principles, pillars, and implications for human action: Literature review. Cogent Soc. Sci. 2019, 5, 1-21. [CrossRef]

53. Bohne, R.A.; Klakegg, O.J.; Lædre, O. Evaluating sustainability of building projects in urban planning. Procedia Econ. Financ. 2015, 21, 306-312. [CrossRef]

54. Palumbo, M. Environment Sustainability of Rail Transportation. 2013. Available online: www.raiwaysignalling.eu (accessed on 22 January 2020).

55. Dasgupta, P. The idea of sustainable development. Sustain. Sci. 2007, 2, 5-11. [CrossRef] 